\title{
Selective glucocorticoid receptor-activating adjuvant therapy in cancer treatments
}

\author{
Nora Sundahl ${ }^{1,2}$, Dorien Clarisse ${ }^{1,2,3}$, Marc Bracke ${ }^{1,2}$, Fritz Offner ${ }^{4}$, Wim Vanden \\ Berghe $^{5}$, Ilse M. Beck ${ }^{1,2, *}$ \\ ${ }^{1}$ Laboratory of Experimental Cancer Research (LECR), Department of Radiation Oncology \& Experimental Cancer Research, \\ Ghent University, Gent, Belgium \\ ${ }^{2}$ Cancer Research Institute Ghent (CRIG), Ghent, Belgium \\ ${ }^{3}$ Receptor Research Laboratories, Nuclear Receptor Lab (NRL), VIB Medical Biotechnology Center, Ghent University, Ghent, \\ Belgium \\ ${ }^{4}$ Hematology, Department of Internal Medicine, Ghent University, Ghent, Belgium \\ ${ }^{5}$ Laboratory of Protein Chemistry, Proteomics and Epigenetic Signaling, Department of Biomedical Sciences, University of \\ Antwerp, Wilrijk, Belgium \\ * From October 2016 onwards, IM Beck can be contacted via Ilse.Beck@odisee.be, affiliation: Health Care Biomedical \\ Laboratory Technology, Technology Campus Ghent, Odisee University College, Ghent, Belgium
}

Correspondence to: Ilse M. Beck, email: Ilse.Beck@ugent.be

Keywords: glucocorticoids, selective glucocorticoid receptor agonist, selective glucocorticoid receptor modulator, cancer, hematological malignancies, therapy resistance

Received: February 11,2016 Accepted: July 08, $2016 \quad$ Published: July 27, 2016

This is an open-access article distributed under the terms of the Creative Commons Attribution License, which permits unrestricted use, distribution, and reproduction in any medium, provided the original author and source are credited.

\section{ABSTRACT}

\begin{abstract}
Although adverse effects and glucocorticoid resistance cripple their chronic use, glucocorticoids form the mainstay therapy for acute and chronic inflammatory disorders, and play an important role in treatment protocols of both lymphoid malignancies and as adjuvant to stimulate therapy tolerability in various solid tumors. Glucocorticoid binding to their designate glucocorticoid receptor (GR), sets off a plethora of cell-specific events including therapeutically desirable effects, such as cell death, as well as undesirable effects, including chemotherapy resistance, systemic side effects and glucocorticoid resistance. In this context, selective GR agonists and modulators (SEGRAMs) with a more restricted GR activity profile have been developed, holding promise for further clinical development in anti-inflammatory and potentially in cancer therapies. Thus far, the research into the prospective benefits of selective GR modulators in cancer therapy limped behind. Our review discusses how selective GR agonists and modulators could improve the therapy regimens for lymphoid malignancies, prostate or breast cancer. We summarize our current knowledge and look forward to where the field should move to in the future. Altogether, our review clarifies novel therapeutic perspectives in cancer modulation via selective GR targeting.
\end{abstract}

\section{INTRODUCTION}

Therapeutic administration of glucocorticoids (GCs) is frequently applied to combat inflammatory, immune and allergic disorders, brain edema, shock and various blood cancers [1-4]. However, in malignancies the effect of GCs is ambiguous; it has an anti-cancer effect in most hematological malignancies [5-8], yet in solid tumors GCs have been shown to inhibit as well as promote tumor progression [9-21]. Recent advances in the development of selective glucocorticoid receptor agonists and modulators (SEGRAMs) have yielded several compounds which bind to GR yet exert a different, more specific, action radius as compared to classic GCs [3, 22-30]. In the light of this 
development, some of these SEGRAMs have also been studied in the context of malignancies [27, 30-45]. In this article we will review what is currently known about the effect of SEGRAMs on the induction and progression of cancer.

\section{GLUCOCORTICOIDS AND GLUCOCORTICOID RECEPTOR FUNCTION}

In its unliganded state, the glucocorticoid receptor (GR) is a predominately cytoplasmic protein and its ligand-binding conformation is maintained by its chaperoning partners in a large multi-protein complex. Nonetheless, GR is able to shuttle between the nucleus and the cytoplasm [46, 47]. The ligand-bound GR is subject to a conformational change and subsequently dissociates from the chaperoning complex. Ligand-bound
GR is guided to the nucleus where it can fuel or inhibit the expression of specific genes via different mechanisms, including binding to glucocorticoid-responsive elements (GREs) in the genes' promoter regions and interacting with other DNA-bound transcription factors, as such influencing gene expression (Figure 1) [48]. Thus, GCs stimulate the expression of anti-inflammatory proteins, metabolic gene products and certain pro-apoptotic proteins [48-51]. They can also inhibit the transcription of pro-inflammatory proteins (e.g. cytokines, enzymes and adhesion molecules) and certain anti-apoptotic proteins through a number of different mechanisms [4952]. Besides these GR-mediated genomic mechanisms, non-genomic GR-mediated mechanisms have been described involving membrane-modulating effects of GCs, modulation of signaling pathways by membraneassociated GRs, cytosolic GRs and mitochondrial GRs [53-58].

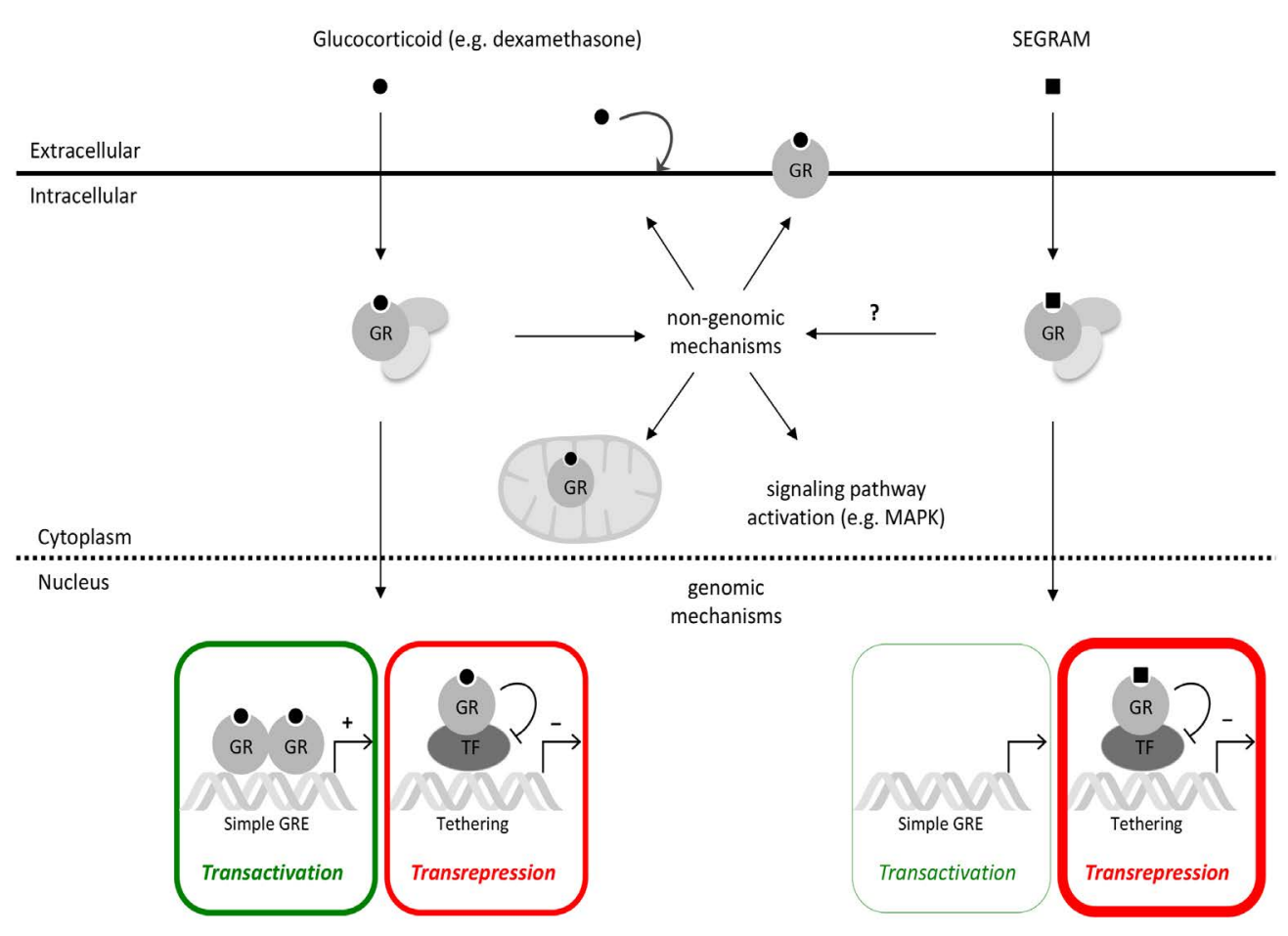

Figure 1: Genomic and non-genomic mechanisms of GR-mediated signaling. Classical GCs such as dexamethasone can enter the cell via passive diffusion and bind to GR. Upon GC binding, GR is released from the multiprotein complex and can execute either genomic or non-genomic mechanisms. The genomic mechanisms include transactivation, promoting transcription of target genes, and transrepression, inhibiting transcription factor (TF)-driven gene expression. The non-genomic mechanisms consist of GCs modulating cell membranes, membrane-bound GR, cytosolic and membrane-bound GR modulating signaling pathways and GR translocation into mitochondria. The SEGRAM-driven GR can, similar to classical GCs, translocate to the nucleus and repress TF-driven (NF- $\mathrm{BB}-\mathrm{and} / \mathrm{or}$ AP-1) driven gene expression, but not (or to a lesser extent) result in the upregulation of GRE-mediated genes such as GILZ. How these SEGRAMs affect non-genomic GR-mediated mechanisms such as kinase activities is unknown. 
Table 1: The effect of glucocorticoids on different tumor entities.

\begin{tabular}{|l|l|l|}
\hline Malignancy & Effects of GCs & Refs \\
\hline Hematological malignancies & $\begin{array}{l}\text { Induction of apoptosis via upregulation of pro-apoptotic genes, } \\
\text { transrepression of NF-kB and AP-1 and non-genomic mechanisms. }\end{array}$ & {$[5,6,63,64,67-71]$} \\
\hline Breast cancer & $\begin{array}{l}\text { Depending on cell type and GR and ER status, inhibition of } \\
\text { chemotherapy-induced apoptosis via inactivation of MAPKs, } \\
\text { transrepression of certain genes and transactivation of DUSP1/ } \\
\text { MKP1 and SGK-1. }\end{array}$ & {$[9,76-79,155]$} \\
\hline Skin tumor & $\begin{array}{l}\text { Prevention of skin tumor promotion. Resistance to GCs in } \\
\text { established papillomas and carcinomas. }\end{array}$ & {$[81-89]$} \\
\hline Prostate cancer & $\begin{array}{l}\text { Progression inhibition in hormone-refractory prostate cancer via } \\
\text { inhibition of adrenal androgen production and the modulation of } \\
\text { gene expression. Progression stimulation in tumors receiving anti- } \\
\text { androgen therapy via diminishing the efficacy of anti-androgen } \\
\text { therapy and transactivation of pro-cell survival genes. }\end{array}$ & {$[18,19,90-95]$} \\
\hline
\end{tabular}

\section{CANCER MODULATION VIA DIRECT OR INDIRECT EFFECTS OF GLUCOCORTICOIDS}

GCs have a variety of cell-specific effects on cancer cells (Table 1). In hematological malignancies GCs can have anti-cancer effects $[7,50,59]$. However, in solid tumors the in vitro and in vivo data are controversial. On the one hand, it has been shown that GCs inhibit apoptosis and prevent chemotherapy-induced apoptosis in most solid malignancies [9-12, 16, 17], thereby stimulating tumor progression as indicated by an increased likelihood of metastasis in breast cancer patients [13,14] or increased risks of skin cancer among users of systemic GCs [15]. Also an elevated risk of non-hodgkin lymphoma was seen among these users of systemic GCs [15]. These results were confirmed by in vitro and in vivo data obtained with various human carcinoma cell lines and mouse tumor xenografts $[12,16]$. On the other hand, GCs have also been identified as a chemosensitizer $[10,60$, 61]. Similarly, in prostate cancer GCs can either inhibit tumor growth or induce chemotherapy resistance [1821]. Nonetheless, GCs have been used in cancer therapy since the 1940s. Nowadays, they are commonly found in the regimens of acute lymphocytic leukemia, chronic lymphocytic leukemia, Hodgkin's and non-Hodgkin's lymphoma, multiple myeloma $[7,8]$ and prostate cancer [18]. Furthermore, they are used as adjuvant therapy in the treatments of various solid tumors to avoid excessive immune reactions and healthy cell toxicity in response to chemotherapy, to reduce nausea and emesis, to decrease swelling, to inhibit tissue reaction (e.g. inflammation) against invasive tumor growth or as palliative treatment of metastasis-related pain [8]. The cancer-modulating mechanisms of GCs are not yet fully understood, but a variety of such mechanisms has been postulated and investigated $[8,18,19,59]$.
In hematological malignancies, the major effect of GCs is induction of apoptosis of cancer cells $[5,6]$. The exact mechanism has not yet completely been clarified. Nevertheless, intervals of continuously administered steroids, e.g. dexamethasone, and sufficient levels of functionally receptive and active GR in malignant lymphoid cells are essential to reach therapy effectiveness. This evokes a culmination of genomic, including transactivation and transrepression, and nongenomic regulatory events, suggesting the involvement of a complex crosstalk between GCs and diverse other signaling pathways [5]. GR transactivation is required for apoptosis via upregulating pro-apoptotic genes, such as Bim and suppressor of AP-1 regulated by interferon (SARI) [6, 62-65]. Other studies stress the importance of $\mathrm{GC}$-induced transrepression of the nuclear factor $\mathrm{\kappa B}$ (NF$\kappa \mathrm{B})$ and activator protein 1 (AP-1) as a driver of apoptosis, impairing transcription of pro-inflammatory cytokines, such as IL-6, anti-apoptotic genes, such as Bcl-xL, and cell cycle promoting genes, such as cyclin D1 [50, 51, $62,66]$. Non-genomic mechanisms such as translocation of GR into mitochondria were shown to reduce the mitochondrial outer membrane potential, promoting the release of cytochrome $\mathrm{C}$, a prerequisite for the activation of the intrinsic apoptotic pathway [56, 67]. Until today, combination of traditional chemotherapies and newer agents (such as proteasomal inhibitors) with GCs remain a cornerstone in the treatment of lymphoid malignancies, especially for multiple myeloma and acute lymphoblastic leukemia therapy [68-71].

During the treatment of breast cancer, GCs are often administrated as an adjuvant therapy to reduce the adverse effects of chemotherapy and to protect the normal tissue against the long-term effects of genotoxic drugs [72]. Yet, in 1958 , an autopsy study on patients with disseminated breast carcinoma showed that $26 \%$ (8 of 31 ) of women who received glucocorticoid treatment developed spleen 
metastases, whereas women who had not received the therapy, did not develop spleen metastases ( 0 of 16) $[11,13,73]$. This was confirmed by a following autopsy study on gastroduodenal metastases, where 29 out of 136 patients $(21 \%)$ who had received corticosteroids developed metastases to the gastroduodenal area as compared to 9 out 68 patients $(13 \%)$ of the control group [73, 74]. GCs can inhibit apoptosis in breast cancer cells in vitro and in vivo [75] . More specifically, they inhibit chemotherapyinduced apoptosis, via GR-mediated inactivation of mitogen-activated protein kinases (MAPKs), GR-mediated inhibition of certain genes, including Insulin-like growth factor-binding protein 3 (IGFBP-3) and tissue plasminogen activator and GR-fueled increased expression of dualspecificity phosphatase 1 (DUSP1)/mitogen-activated protein kinase phosphatase-1 (MKP1) and serum/ glucocorticoid regulated kinase 1 (SGK-1) [10, 76-79]. The latter mechanism suggests that transrepressive GC compounds lacking transactivation may remain effective while reducing adverse effects. Regardless of the negative impact of exogenous GC administration, GR expression itself is not a reliable prognostic factor for tumor size, stage and grade. Moreover, sustainable expression of GR has been associated with several beneficial outcome features, among which estrogen receptor, progesteron receptor, Forkhead Box A1, GATA -binding protein 3 and brain-expressed X-linked 1 (BEX1) expression [80].

In skin tumor models, induced by chrysarobin, 7-bromomethylbenz[a]anthracene (BrMBA) or 12-O-tetradecanoylphorbol-13-acetate (TPA), GCs can prevent skin tumor promotion in vitro and in vivo [81-86]. Furthermore, transgenic animals expressing high levels of GR in the skin seemed to be highly resistant to skin tumor development [83, 87]. However, several tumorigenic keratinocyte cell lines appeared functionally GC-resistant to $\mathrm{GC}$-induced growth arrest, regardless of the high levels of GR mRNA and protein [88]. Moreover, established papillomas and carcinomas appear to be resistant to GCs $[88,89]$.

The role of GR in prostate cancer is rather ambiguous. On the one hand, GCs are often a part of complex chemotherapy in advanced hormone-refractory prostate cancer. Their anti-cancer effects are attributed primarily to their inhibitory effect on adrenal androgen

\section{Classic GR agonists \\ Steroidal}

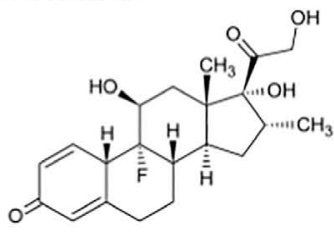

Dexamethasone

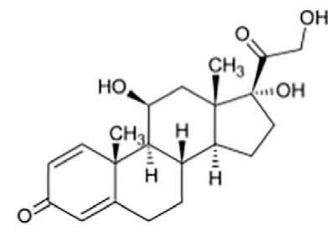

Prednisolone

\section{Selective GR agonists and modulators}

\section{Steroidal}

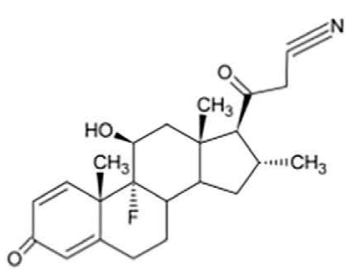

RU24858

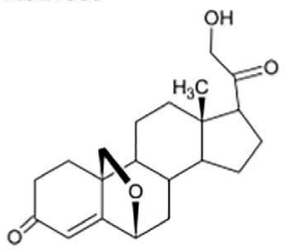

$210 \mathrm{H}-6,190 \mathrm{P}$
Non-steroidal

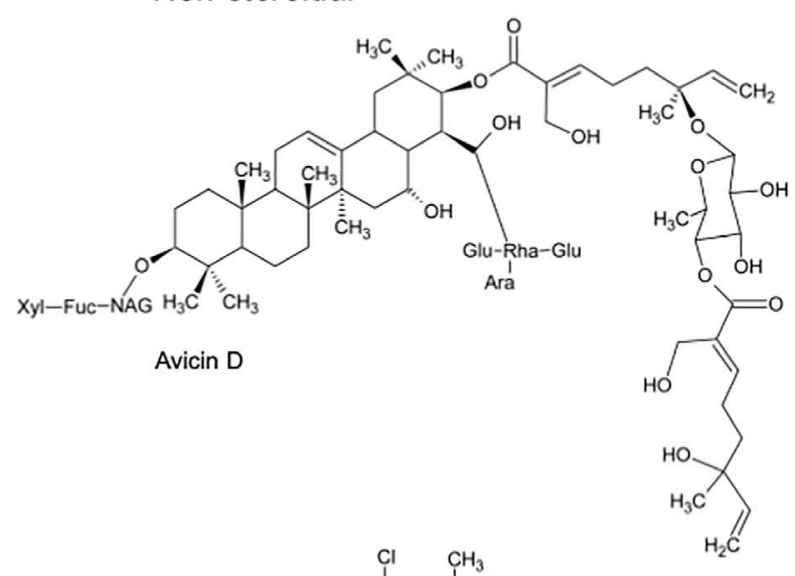

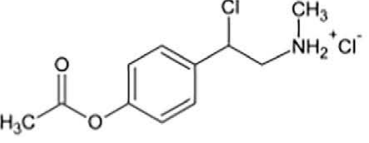

Compound $\mathrm{A}$

Figure 2: Chemical structures of discussed GR-targeting compounds. Classical GR agonists such as dexamethasone and prednisolone have a steroidal skeleton. Selective GR agonists and modulators are divided in two categories: steroidal, RU24858 and $21 \mathrm{OH}-$ 6,19OP, and non-steroidal, avicin D and compound A, compounds. 
production. Recent evidence shows that GCs also directly target prostate cancer cells through modulation of the expression of genes regulating growth, apoptosis, inflammation, metastasis, differentiation, cell survival and angiogenesis [18, 19, 90-93]. On the other hand, prostate tumors that have received prolonged androgen receptor (AR)-blocking anti-androgen therapy (e.g. enzalutamide) display a relatively higher GR expression level which rather increases cell viability and facilitates progression in vivo $[94,95]$. GR-mediated actions also diminish the efficacy of AR inhibition therapy and even stimulate the expression of pro-cell survival genes. In some prostate cancers anti-androgen resistance has been linked to upregulation of GR. Since GR and AR have partially overlapping target genes, upregulation of GR may restore the transcription of one or more AR target genes following AR inhibition therapy [94]. This puts forth the idea that whereas GR activation has a detrimental effect on AR signaling-deficient prostate cancer, it can also inhibit the progression of prostate cancers from androgen dependence to hormone resistance as long as AR is still functionally active.

The effect of GCs on the efficiency of chemotherapy and radiotherapy is controversial. In several established cell lines as well as primary carcinoma cells from solid tumors (i.e. bone, brain, breast, cervix, melanoma and neuroblastoma) GCs could prevent chemotherapy-induced cell death and even promote proliferation $[12,75,96-$ 110]. Also in the clinical setting, it has been observed that concomitant combination chemotherapy with GCs resulted in a worse outcome than single chemotherapy [111, 112]. In radiotherapy mouse models, GCs could have an indirect positive effect on radiosensitivity via decreasing tumor oxygen consumption, and thereby enhancing tumor oxygenation [113]. Paradoxically, GC-induced resistance to radiotherapy [114] and GR antagonist-enhanced radiosensitivity have also been reported $[115,116]$.

\section{SELECTIVE GLUCOCORTICOID RECEPTOR AGONISTS AND MODULATORS (SEGRAMS)}

Selective glucocorticoid receptor agonists and modulators (SEGRAMs) are a class of compounds which act on GR in analogy to GC, yet affect GR-mediated gene expression in a different manner, skewing the bulk of gene expression modulation to either transrepression or transactivation, but with the intention to improve the therapeutic efficacy. Although in inflammatory afflictions, a new model balancing transrepression and transactivation more carefully is now appearing $[3,22$, 23], a few decades ago the key anti-inflammatory effect of GR was attributed to its transrepression mechanism [117-119], while the majority of GC-associated side effects was originally ascribed to GR transactivation [120]. This pharmacological model launched a series of compounds exerting primarily transrepressive effects of GR for treatment of inflammatory disorders [3]. As such, RU24858 [24], 21OH-6,19OP [25, 26], avicin D [27], compound A (CpdA) [28], (Figure 2) and many more [3, 29] have been classified as SEGRAMs.

How shifting the balance to a relative preponderance in GR transactivation or GR transrepression affects therapeutic efficacy related to tumor development, tumor growth, tumor cell apoptosis or GC/GR-induced chemotherapy resistance is not completely clear yet. But since it is known that GR can affect malignancies in a stimulating and inhibiting manner (as discussed above), increased interest into whether SEGRAMs can skew the action radius of GR to solely tumor suppression spikes in literature.

Evidence that GR transrepression and GR transactivation can be dissociated originates from a pioneering study with a GR dimerization mutant (GRdim) [117]. This mutant harboring a point mutation in the second zinc finger of the GR DNA-binding domain, has difficulties forming GR homodimers, which abrogates high affinity binding to GRE motifs at specific gene promoters. This abolishes to a large extent GR transactivation effects whereas transrepression capacity remains largely unaffected [121, 122]. In multiple myeloma, GRdimbased experiments reveal a specific role for classic GR transactivation in GR-mediated apoptosis [123].

The well-known GR antagonist RU486 (also known as mifepristone), is incorporated into various cancer regimens because of its antineoplastic potential. However, RU486 is also a progesterone and androgen receptor antagonist, and most research attributes the antineoplastic effect to the antagonism of the progesterone receptor [124]. Yet, current findings question this hypothesis [125]. Since RU486 has an antagonistic effect and is not GR specific, it is not considered a SEGRAM.

Our review will particularly focus on RU24858, 21OH-6,19OP, Avicin D and CpdA, as these are the only SEGRAMs, for which potential cancer-modulating properties have been reported so far.

The underlying mechanism for differential GR regulation by SEGRAMs and GCs has not completely been resolved. CpdA [28], avicin D [27], RU24858 [126] and 21OH-6,19OP [127] can instigate a GR translocation to the nucleus in analogy to classic GCs (e.g. dexamethasone), although potencies may vary [38, 128130]. Research indicates that CpdA [28], RU24858 [126] and 21OH-6,19OP [131] induce a different conformational change in GR than GCs do. In silico modeling maps CpdA [38], RU24858 [126] and 21OH-6,19OP [132] in the ligand-binding pocket of GR; whether this is also the case for avicin D is still unknown. However, even though the virtual docking studies show that CpdA could bind in the ligand-binding pocket, additional structural studies are still required. While CpdA promotes a monomeric GR conformation $[127,130]$, the compound $21 \mathrm{OH}-6,19 \mathrm{OP}$ 
Table 2: Binding affinity of discussed SEGRAMs to GR.

SEGRAM-mediated binding to GR

\begin{tabular}{|l|l|l|l|}
\hline SEGRAM & GR, origin & GR binding & Ref \\
\hline RU24858 & A549 cells, h & $\mathrm{Ki}=110.0 \pm 24.0 \mathrm{nM}$ & {$[134]$} \\
\hline 21OH-6,19OP & rat thymus & Kd $=125 \mathrm{nM}$ (RBA for GR as compared to corticosterone) & {$[26]$} \\
\hline Avicin D & A549 cells, h & $\begin{array}{l}\text { competition for Dex 35\% (with 5-fold excess); 85\% (with 500-fold } \\
\text { excess) }\end{array}$ & {$[27]$} \\
\hline CpdA & L929sA, m & IC50 $=6.4 \mathrm{nM}(\mathrm{CI} 1.9-20.5 \mathrm{nM})$ & {$[28]$} \\
\hline & BWTG3, $\mathrm{m}$ & $\mathrm{Kd}=81.8 \mathrm{nM}$ & {$[156]$} \\
\hline & COS-1, s, TT hGR & IC50 $=0.003 \pm 0.004 \mathrm{nM}$ & {$[157]$} \\
\hline & DU145 cells, h & competition for Dex 85\% (with 100-fold molar excess) & {$[38]$} \\
\hline & A549 cells, h & Ki $=4,9 \pm 1.3 \mathrm{nM}$ & {$[134]$} \\
\hline & L929sA, m & IC50 $=25.9 \mathrm{nM}(\mathrm{CI} 7.9-84 \mathrm{nM})$ & {$[28]$} \\
\hline & BWTG3, m & Kd $=1.29 \mathrm{nM}$ & {$[156]$} \\
\hline & COS-1, s, TT hGR & IC50 $=14 \pm 4 \mathrm{nM}$ & {$[157]$} \\
\hline
\end{tabular}

Abbreviations: RBA, relative binding affinity; $\mathrm{CI}$, confidence interval; $h$, human; $\mathrm{m}$, murine; s, simian; $\Pi$, transiently transfected; IC50, concentration at which compound inhibited $50 \%$ of specific binding of labeled dexamethasone.

[25] drives GR to a dimeric formation, just as GCs do. It still needs to be investigated whether RU24858 and avicin $\mathrm{D}$ favor a predominately monomeric or dimeric GR conformation. The binding affinity to GR of the discussed SEGRAMs can be found in Table 2.

Similarly to classical GCs, CpdA [133], avicin D [27], 21OH-6,19OP [25, 26], and RU24858 [134], efficiently downregulate the transcription of TNF-induced and NF-kB-dependent pro-inflammatory genes (e.g., IL-6, IL-8, E-selectin) (Figure 1) [28].

In contrast to classical GCs, CpdA [28], avicin D [27] and 21OH-6,19OP [132] do not stimulate endogenous GRE-dependent genes. This means that these compounds only exhibit transrepression effects, but lack transactivation capacity (Table 3 ) [27, 28]. This is in contrast to RU24858 [126] which still induces GR transactivation in selected cell types [135]. In mouse models, in contrast to dexamethasone, CpdA shows antiinflammatory effects and displays reduced GC side-effects because it does not induce hyperglycemia (potentially leading to diabetes) [28, 136], hyperinsulinemia [130] or skin atrophy [137] and does not elevate AST and ALT enzyme levels (which is a sign of liver toxicity) [138]. Endogenous cortisol levels are also maintained by CpdA [138]. Finally, whereas prolonged GC treatment frequently downregulates GR levels and contributes to the onset of $\mathrm{GC}$ resistance, prolonged CpdA treatment does not decrease GR levels, allowing sustainable anti-inflammatory effects [122, 128, 139]. Research investigating the in vivo adverse effects of the SEGRAMs RU24858, 21OH-6,19OP and avicin D is yet to be performed. How the SEGRAMs RU24858, 21OH-6,19OP, avicin D and CpdA affect the non-genomic effects of GR is currently still largely unknown.

\section{SEGRAMS' CANCER-MODULATING POTENTIAL}

Although the SEGRAMs discussed below are not the only SEGRAMs known to literature [3, 29], they are the only ones to our knowledge that have been evaluated for their cancer-modulating potential (Figure 3).

\section{RU24858}

It has been revealed by competition assays in vitro that the SEGRA RU24858 binds GR with similar affinity as dexamethasone [24]. Since GCs can prevent skin cancer formation elicited by specific chemicals or ultraviolet radiation in animal models [82, 140, 141], the dissociated compounds RU24858 and RU24782 have been investigated in this setting. In a SENsitivity to CARcinogenesis (SENCAR) mouse model classical GCs 


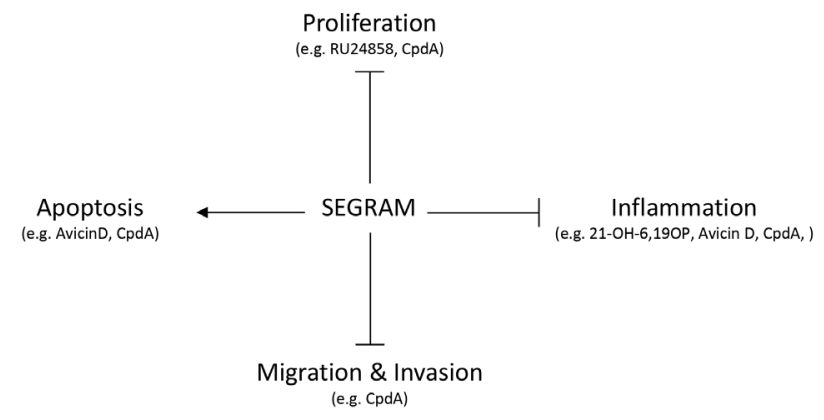

Figure 3: SEGRAM-triggered mechanisms in cancer. SEGRAMs have anti-inflammatory properties, can inhibit proliferation, migration and invasion, and can induce apoptosis of cancer cells. However, the specific action mechanism depends on the SEGRAM itself and on the tissue type.

and the compound RU24858 were both able to prevent epidermal hyperplasia and proliferation elicited by exposure to tumor-promoting TPA. The anti-proliferative and anti-hyperplastic effects of RU24858 in these mice were weaker than that of the classic GCs. Furthermore, RU24858 was also able to reverse the induction of TPA-induced genes, associated in skin tumor promotion (such as c-Jun, COX-2 and iNOS) [31]. In contrast, the comparable compound RU24782, which has a thioether functional group instead of a nitrile functional group as compared to RU24858, failed to elicit anti-cancer activities [31]. The different behavior of these SEGRAs could be due to a varying inhibition of NF- $\mathrm{KB}$ and/ or a varying ability to interact with repressive histone deacetylases [31, 142-144].

\section{H-6,19OP}

$21 \mathrm{OH}-6,19 \mathrm{OP}$ is a selective GR agonist, which lacks the bulky substituent at $\mathrm{C}-11$, found in active GR antagonists [26, 145]. This compound is able to transrepress AP-1 and NF- $\mathrm{kB}$ pathways in COS-1, RAW 264.7 and BHK cells, yet not in A549 lung cancer cells $[25,37,132]$. In the latter cells, $21 \mathrm{OH}-6,19 \mathrm{OP}$ was shown to block TNF-induced COX2 and IL-8 expression [37]. Furthermore, it is largely incapable of inducing transcription of GRE-regulated genes $[25,26]$ and, when incubated in combination with dexamethasone, it acts as an antagonist to GR transactivation [26]. These findings indicate that $21 \mathrm{OH}-6,19 \mathrm{OP}$ is a cell-specific, selective GR agonist. Noteworthy, 21OH-6,19OP is capable of upregulating DUSP1, most likely contributing to its cytokine-inhibiting capacities [37].

As it is known that GCs, administered for symptomreducing reasons, can induce chemoresistance in certain malignancies [11], SEGRAM-based research could shed light on the mechanistic $21 \mathrm{OH}-6,19 \mathrm{OP}$ basis of this phenomenon. $21 \mathrm{OH}-6,19 \mathrm{OP}$ could circumvent this mechanism as in vitro and in vivo research indicates that contrary to the classic GC dexamethasone, 21OH-6,19OP does not preclude cell death triggered by the anthracyclin doxorubicin in mammary tumor cells. Concomitantly, 210H-6,19OP does not avert paclitaxel-stimulated caspase- 3 activation and does not stimulate anti-apoptotic $\mathrm{BCL}-\mathrm{X}_{\mathrm{L}}$ isoform gene expression [37].

\section{Avicin D}

Avicin D [30] is a desert plant-derived triterpenoid saponin [32], with GR-mediated anti-inflammatory effects [27]. It has also been shown that avicin D induces apoptosis in a variety of human tumor cell lines, such as T-cell leukemia cells (Jurkat cells), breast cancer cells (MDA-MB-435), prostate cancer cells (PC3) and cutaneous T-cell lymphoma cells (CTCL) [27, 30, 32-36]. Contrary to its anti-inflammatory effects, current research indicates that avicin D's cytotoxicity is GR-independent [27]. The underlying mechanism of apoptosis induction is most likely a direct effect of avicin D on mitochondrial bioenergetics which subsequently triggers the apoptosis cascade $[33,146,147]$.

\section{Compound A}

Compound $\mathrm{A}$ is a desert plant-derived SEGRM that exhibits GR transrepression capacities, and lacks the ability to fuel classic GR transactivation. In malignant prostate, bladder, leukemia and multiple myeloma cell lines and primary leukemia cells, CpdA can induce apoptosis [38-42]. Contrary to avicin D, its pro-apoptotic and cytotoxic effects are reported to be partially GRdependent $[38,39,41,42]$.

In advanced prostate cancer, activation of the AR has a pro-tumorigenic effect, whereas exclusive activation of GR can have an anti-tumorigenic effect $[18,19,90$ 93]. The SEGRM CpdA can affect both of these steroid receptors in different cell lines, among which prostate cancer cells [38, 43]. Virtual docking studies showed that CpdA was able to bind the AR. However, CpdA was not able to compete for binding to the AR, in contrast to the androgen mibolerone. Nevertheless, CpdA induces the nuclear translocation of AR, but inhibited AR DNA binding and AR transcriptional activity $[38,43]$. Thus, the effect of CpdA resembles the effect of anti-androgens, commonly used in the therapy of prostate cancer [43]. CpdA shifts the activity of GR towards transrepression, theoretically resulting in the inhibition of proproliferative and anti-apoptotic gene expression. However, experimental evidence to substantiate this is currently lacking. Remarkably, CpdA seems able to upregulate the protein levels of pro-apoptotic Bim and tumor suppressor p53 in both CEM and K562 leukemia cells [40].

CpdA's selective GR actions and to a lesser extent its antagonistic AR actions also contribute to the compound's 
ability to inhibit bladder cancer cell proliferation, colony formation, cell migration and invasion, and to increase cell cycle arrest and apoptosis [41]. The combination of AR blockage and GR-mediated transrepression resulted in an inhibition of prostate tumor growth in vitro [38] and bladder cancer cell xenograft growth in vivo [41]. Furthermore, CpdA induced increased caspase activation and PARP cleavage in these prostate cancer cells [38].

Currently, the proteasomal inhibitor bortezomib is often used in therapy for lymphomas and myelomas [148]. The combination of bortezomib and GCs has been proven to act synergistic in hemoblastoses [149]. This synergistic effect may be explained in several different ways. The proteasome inhibitor prevents GR cleavage, consequently GR levels rise and GR activity is reinforced. In addition, GCs enhance the expression of proteins implicated in the development of ER stress [40], and excessive ER stress induces apoptosis and sensitizes cells to bortezomibinduced apoptosis [150]. CpdA treatment had a more prominent cytostatic and apoptotic effect on leukemia cells as compared to treatment with the GC fluocinolone acetonide. Furthermore, the combined treatment with bortezomib and $\mathrm{CpdA}$ showed that $\mathrm{CpdA}$ potentiated the cytotoxic effect of bortezomib [40].

In breast cancer, Chen et al. recently discovered that dexamethasone, but not CpdA treatment clearly protects triple negative breast cancer cells (MDA-MB-231) from paclitaxel-induced growth inhibition [44]. Moreover, Chip-exo-based studies confirm that Dex-liganded, but not CpdA-liganded, GR can bind to a single GRE, which drives the expression of pro-tumorigenic genes. From the transrepression perspective, AP-1 and NF- $\mathrm{BB}$-enriched motifs in triple negative breast cancer cells do not attract a tethering CpdA-liganded GR. Actually CpdA alters the expression of only a small number of genes that are not involved in carcinogenesis and therapy resistance [44]. These findings suggest that tweaking the action radius of GR may lead to a safer coadjuvant for chemotherapy for breast cancer.

In contrast to classic GCs and RU24858 [31], CpdA was not able to inhibit TPA-induced skin epidermal thickening and proliferation. Moreover, it even increased, yet to a lesser extent than TPA, the epidermal thickness and proliferation of keratinocytes in an in vivo model of SENCAR mice [45]. This effect can possibly be explained by the fact that CpdA-bound GR does not transrepress AP-1-regulated genes in particular cell types, and as such may be less effective in suppressing transcription of tumorigenesis-associated genes c-Jun, COX-2, and IL-6 [133]. Yet, CpdA was able to decrease the expression of the p50 subunit of NF- $\kappa \mathrm{B}$ in these SENCAR mice. Of special note, since NF- $\kappa \mathrm{B}$ is constitutively activated in 7,12-dimethylbenz[a]anthracene (DMBA)/TPApromoted mouse skin tumors, partially due to an increase in expression/activation of p50, this pathway could have an interesting anti-tumoral potential [45].
Furthermore, the effect of CpdA was recently also investigated on cancer-surrounding cells, namely colon cancer-derived myofibroblasts, which influence cancer cells via cell-to-cell or paracrine signaling. This research revealed that in comparison to dexamethasone, CpdA only had minor impact on gene expression and protein levels of cancer-promoting factors [128].

\section{DISCUSSION}

Although the cell type-specific anti-cancer potential of GCs involves inhibition of growth and induction of apoptosis, the mechanism by which GCs are able to do this has not been completely elucidated. Further research with currently available anti-inflammatory SEGRAMs, under clinical evaluation [3], will allow to dissect the mechanism of action of GR in neoplastic tissue. This will entail the design of SEGRAMs with very specific mechanisms of action to fight against cancer.

Despite its widespread use, chronic exposure to GCs in cancer treatments is severely limited by the vast range of side effects it induces or the development of therapy resistance [2]. Therefore, the development of clinically more selective compounds that exert the activation or inhibition of a subset of pathways may result in a more focused anti-cancer action, reduced risk of therapy resistance, but also a significant reduction in side effects and thus more comfort for the patient. Along the same line, the development of selective estrogen receptor modulators and selective androgen receptor modulators has yielded compounds with improved anti-cancer action and reduced side effects. Their selective action radius has allowed these compounds to be used also in primary prevention regimens against cancer (e.g. tamoxifen in breast cancer) [151], besides their classical use in integral cancer therapy, like chemotherapeutic agents such as cisplatin or paclitaxel. Spatiotemporal delivery restrictions could aid to confine the compounds' actions even further and thus limit the side effect profile and increase its efficiency. The development of a liver-specific GR antagonist A-348441 (now called KB3305) with a clinical proof-of-concept shows that it is feasible to develop tissue- or organ-specific GR-targeting compounds [152]. In the framework of solid tumors and the associated leaky vasculature, recent work in metastatic prostate cancer bone lesions shows that liposomal encapsulated dexamethasone is delivered to these malignant bone lesions and sometimes inhibits in vivo tumor growth more efficiently than systemic administration of dexamethasone [153]. Also the recent research proving the anti-cancer effect of cationic lipidconjugated hydrocortisone, which selectively targets cancer cells endorses the possibility of cell-type specific GR-targeting compounds [154].

In conclusion, combining selective GR modulator compounds, with innovative tissue- or cell- specific delivery methods may allow to further optimize 
therapeutic efficacy and reduce adverse GC-associated side effects. Further investigation of selective modes of action of GR should allow further development of GR dependent anti-cancer compounds for various malignancies, with improved specificity and optimized therapeutic window.

\section{ACKNOWLEDGEMENTS}

We are grateful to the Research Foundation-Flanders (FWO) for funding of a postdoctoral fellowship for I. M. Beck and the Agency for Innovation by Science and Technology (IWT) for funding the predoctoral fellowship of D. Clarisse. The work of D. Clarisse and I. M. Beck is additionally supported by a grant from the Flemish League against Cancer (VLK - Vlaamse Liga tegen Kanker). Research by W. Vanden Berghe and F. Offner is supported by the FWO grants G079614N and G059713N. The funding agencies had no role in design, analyses, decision to publish, or preparation of the manuscript. The authors declare that there are no conflicts of interest.

\section{REFERENCES}

1. McMaster A and Ray DW. Drug insight: selective agonists and antagonists of the glucocorticoid receptor. Nat Clin Pract Endocrinol Metab. 2008; 4(2):91-101.

2. De Bosscher K and Haegeman G. Minireview: latest perspectives on antiinflammatory actions of glucocorticoids. Mol Endocrinol. 2009; 23(3):281-291.

3. Sundahl N, Bridelance J, Libert C, De Bosscher K and Beck IM. Selective glucocorticoid receptor modulation: New directions with non-steroidal scaffolds. Pharmacol Ther. 2015; 152:28-41

4. Dietrich J, Rao K, Pastorino S and Kesari S. Corticosteroids in brain cancer patients: benefits and pitfalls. Expert Rev Clin Pharmacol. 2011; 4(2):233-242.

5. Ahmad N and Kumar R. Steroid hormone receptors in cancer development: a target for cancer therapeutics. Cancer Lett. 2011; 300(1):1-9.

6. Smith LK and Cidlowski JA. Glucocorticoid-induced apoptosis of healthy and malignant lymphocytes. Prog Brain Res. 2010; 182:1-30.

7. Wooldridge JE, Anderson CM and Perry MC. Corticosteroids in advanced cancer. Oncology (Williston Park, NY). 2001; 15(2):225-234; discussion 234-226.

8. Schlossmacher G, Stevens A and White A. Glucocorticoid receptor-mediated apoptosis: mechanisms of resistance in cancer cells. J Endocrinol. 2011; 211(1):17-25.

9. Pang D, Kocherginsky M, Krausz T, Kim SY and Conzen SD. Dexamethasone decreases xenograft response to Paclitaxel through inhibition of tumor cell apoptosis. Cancer Biol Ther. 2006; 5(8):933-940.

10. Moutsatsou P and Papavassiliou AG. The glucocorticoid receptor signalling in breast cancer. J Cell Mol Med. 2008;
12(1):145-163.

11. Zhang C, Beckermann B, Kallifatidis G, Liu Z, Rittgen W, Edler L, Buchler P, Debatin KM, Buchler MW, Friess H and Herr I. Corticosteroids induce chemotherapy resistance in the majority of tumour cells from bone, brain, breast, cervix, melanoma and neuroblastoma. Int J Oncol. 2006; 29(5):1295-1301.

12. Herr I and Pfitzenmaier J. Glucocorticoid use in prostate cancer and other solid tumours: implications for effectiveness of cytotoxic treatment and metastases. Lancet Oncol. 2006; 7(5):425-430.

13. Iversen HG and Hjort GH. The influence of corticoid steroids on the frequency of spleen metastases in patients with breast cancer. Acta Pathol Microbiol Scand. 1958; 44(2):205-212.

14. Sherlock P and Hartmann WH. Adrenal steroids and the pattern of metastases of breast cancer. JAMA. 1962; 181:313-317.

15. Sorensen HT, Mellemkjaer L, Nielsen GL, Baron JA, Olsen JH and Karagas MR. Skin cancers and non-hodgkin lymphoma among users of systemic glucocorticoids: a population-based cohort study. J Natl Cancer Inst. 2004; 96(9):709-711.

16. Volden PA and Conzen SD. The influence of glucocorticoid signaling on tumor progression. Brain Behav Immun. 2013; 30 Suppl:S26-31.

17. Haid M. Steroid antiemesis may be harmful. N Engl J Med. 1981; 304(20):1237.

18. Kassi E and Moutsatsou P. Glucocorticoid receptor signaling and prostate cancer. Cancer Lett. 2011; 302(1):110.

19. Yemelyanov A, Czwornog J, Chebotaev D, Karseladze A, Kulevitch E, Yang X and Budunova I. Tumor suppressor activity of glucocorticoid receptor in the prostate. Oncogene. 2007; 26(13):1885-1896.

20. Claessens F, Helsen C, Prekovic S, Van den Broeck T, Spans L, Van Poppel H and Joniau S. Emerging mechanisms of enzalutamide resistance in prostate cancer. Nat Rev Urol. 2014; 11(12):712-716.

21. Venkitaraman R, Thomas K, Huddart RA, Horwich A, Dearnaley DP and Parker CC. Efficacy of low-dose dexamethasone in castration-refractory prostate cancer. BJU Int. 2008; 101(4):440-443.

22. Ayroldi E, Macchiarulo A and Riccardi C. Targeting glucocorticoid side effects: selective glucocorticoid receptor modulator or glucocorticoid-induced leucine zipper? A perspective. FASEB J. 2014; 28(12):5055-5070.

23. De Bosscher K, Beck IM, Ratman D, Vanden Berghe $\mathrm{W}$ and Libert C. Glucocorticoid Receptor Activation in Acute Inflammation: The SEDIGRAM Concept. Trends Pharmacol Sci. 2016; 37(1):4-16.

24. Vayssiere BM, Dupont S, Choquart A, Petit F, Garcia T, Marchandeau C, Gronemeyer H and Resche-Rigon M. Synthetic glucocorticoids that dissociate transactivation and 
AP-1 transrepression exhibit antiinflammatory activity in vivo. Mol. Endocrinol. (Baltimore, Md). 1997; 11(9):12451255.

25. Presman DM, Alvarez LD, Levi V, Eduardo S, Digman MA, Marti MA, Veleiro AS, Burton G and Pecci A. Insights on glucocorticoid receptor activity modulation through the binding of rigid steroids. PloS one. 2010; 5(10):e13279.

26. Vicent GP, Monteserin MC, Veleiro AS, Burton G, Lantos CP and Galigniana MD. 21-Hydroxy-6,19oxidoprogesterone: a novel synthetic steroid with specific antiglucocorticoid properties in the rat. Mol. Pharmacol. 1997; 52(4):749-753.

27. Haridas V, Xu ZX, Kitchen D, Jiang A, Michels P and Gutterman JU. The anticancer plant triterpenoid, avicin D, regulates glucocorticoid receptor signaling: implications for cellular metabolism. PLoS One. 2011; 6(11):e28037.

28. De Bosscher K, Vanden Berghe W, Beck IM, Van Molle W, Hennuyer N, Hapgood J, Libert C, Staels B, Louw A and Haegeman G. A fully dissociated compound of plant origin for inflammatory gene repression. Proc Natl Acad Sci U S A. 2005 ; 102(44):15827-15832.

29. Burris TP, Solt LA, Wang Y, Crumbley C, Banerjee S, Griffett K, Lundasen T, Hughes T and Kojetin DJ. Nuclear receptors and their selective pharmacologic modulators. Pharmacol Rev. 2013; 65(2):710-778.

30. Jayatilake GS, Freeberg DR, Liu Z, Richheimer SL, Blake Nieto ME, Bailey DT, Haridas V and Gutterman JU. Isolation and structures of avicins $\mathrm{D}$ and $\mathrm{G}$ : in vitro tumorinhibitory saponins derived from Acacia victoriae. J Nat Prod. 2003; 66(6):779-783.

31. Kowalczyk P, Junco JJ, Kowalczyk MC, Sosnowska R, Tolstykh O, Walaszek Z, Hanausek M and Slaga TJ. The effects of dissociated glucocorticoids RU24858 and RU24782 on TPA-induced skin tumor promotion biomarkers in SENCAR mice. Mol Carcinog. 2014; 53(6):488-497.

32. Mujoo K, Haridas V, Hoffmann JJ, Wachter GA, Hutter LK, Lu Y, Blake ME, Jayatilake GS, Bailey D, Mills GB and Gutterman JU. Triterpenoid saponins from Acacia victoriae (Bentham) decrease tumor cell proliferation and induce apoptosis. Cancer Res. 2001; 61(14):5486-5490.

33. Haridas V, Higuchi M, Jayatilake GS, Bailey D, Mujoo K, Blake ME, Arntzen CJ and Gutterman JU. Avicins: triterpenoid saponins from Acacia victoriae (Bentham) induce apoptosis by mitochondrial perturbation. Proc Natl Acad Sci U S A. 2001; 98(10):5821-5826.

34. Arias M, Quijano JC, Haridas V, Gutterman JU and Lemeshko VV. Red blood cell permeabilization by hypotonic treatments, saponin, and anticancer avicins. Biochimica et biophysica acta. 2010; 1798(6):1189-1196.

35. Zhang C, Li B, Gaikwad AS, Haridas V, Xu Z, Gutterman JU and Duvic M. Avicin D selectively induces apoptosis and downregulates p-STAT-3, bcl-2, and survivin in cutaneous T-cell lymphoma cells. J Invest Dermatol. 2008; 128(11):2728-2735.
36. Haridas V, Arntzen CJ and Gutterman JU. Avicins, a family of triterpenoid saponins from Acacia victoriae (Bentham), inhibit activation of nuclear factor-kappaB by inhibiting both its nuclear localization and ability to bind DNA. Proc Natl Acad Sci U S A. 2001; 98(20):11557-11562.

37. Orqueda AJ, Dansey MV, Espanol A, Veleiro AS, Bal de Kier Joffe E, Sales ME, Burton G and Pecci A. The rigid steroid 21-hydroxy-6,19-epoxyprogesterone (21OH$6,19 \mathrm{OP})$ is a dissociated glucocorticoid receptor modulator potentially useful as a novel coadjuvant in breast cancer chemotherapy. Biochem Pharmacol. 2014; 89(4):526-535.

38. Yemelyanov A, Czwornog J, Gera L, Joshi S, Chatterton RT, Jr. and Budunova I. Novel steroid receptor phyto-modulator compound a inhibits growth and survival of prostate cancer cells. Cancer Res. 2008; 68(12):4763-4773.

39. Lesovaya E, Yemelyanov A, Kirsanov K, Popa A, Belitsky G, Yakubovskaya M, Gordon LI, Rosen ST and Budunova I. Combination of a selective activator of the glucocorticoid receptor Compound $\mathrm{A}$ with a proteasome inhibitor as a novel strategy for chemotherapy of hematologic malignancies. Cell Cycle. 2013; 12(1):133-144.

40. Lesovaya EA, Yemelyanov AY, Kirsanov KI, Yakubovskaya MG and Budunova IV. Antitumor effect of non-steroid glucocorticoid receptor ligand CpdA on leukemia cell lines CEM and K562. Biochemistry (Mosc). 2011; 76(11):12421252 .

41. Zheng $\mathrm{Y}$, Ishiguro $\mathrm{H}$, Ide $\mathrm{H}$, Inoue $\mathrm{S}$, Kashiwagi $\mathrm{E}$, Kawahara T, Jalalizadeh M, Reis LO and Miyamoto H. Compound A Inhibits Bladder Cancer Growth Predominantly via Glucocorticoid Receptor Transrepression. Mol Endocrinol. 2015; 29(10):1486-97.

42. Lesovaya E, Yemelyanov A, Swart AC, Swart P, Haegeman $\mathrm{G}$ and Budunova I. Discovery of Compound A - a selective activator of the glucocorticoid receptor with antiinflammatory and anti-cancer activity. Oncotarget. 2015; 6(31):30730-30744. doi: 10.18632/oncotarget.5078.

43. Tanner TM, Verrijdt G, Rombauts W, Louw A, Hapgood JP and Claessens F. Anti-androgenic properties of Compound A, an analog of a non-steroidal plant compound. Mol Cell Endocrinol. 2003; 201(1-2):155-164.

44. Chen Z, Lan X, Wu D, Sunkel B, Ye Z, Huang J, Liu Z, Clinton SK, Jin VX and Wang Q. Ligand-dependent genomic function of glucocorticoid receptor in triplenegative breast cancer. Nat Commun. 2015; 6:8323.

45. Kowalczyk P, Kowalczyk MC, Junco JJ, Tolstykh O, Kinjo T, Truong H, Walaszek Z, Hanausek M and Slaga TJ. The possible separation of 12-O-tetradecanoylphorbol13-acetate-induced skin inflammation and hyperplasia by compound A. Mol Carcinog. 2013; 52(6):488-496.

46. Hache RJ, Tse R, Reich T, Savory JG and Lefebvre YA. Nucleocytoplasmic trafficking of steroid-free glucocorticoid receptor. J Biol Chem. 1999; 274(3):1432-1439.

47. Vandevyver S, Dejager L and Libert C. On the trail of the glucocorticoid receptor: into the nucleus and back. Traffic. 2012; 13(3):364-374. 
48. Kino T, Charmandari E and Chrousos GP. Glucocorticoid receptor: implications for rheumatic diseases. Clin Exp Rheumatol. 2011; 29(5 Suppl 68):S32-41.

49. Labeur M and Holsboer F. Molecular mechanisms of glucocorticoid receptor signaling. Medicina (B Aires). 2010; 70(5):457-462.

50. Herold MJ, McPherson KG and Reichardt HM. Glucocorticoids in T cell apoptosis and function. Cell Mol Life Sci. 2006; 63(1):60-72.

51. Frankfurt O and Rosen ST. Mechanisms of glucocorticoidinduced apoptosis in hematologic malignancies: updates. Curr Opin Oncol. 2004; 16(6):553-563.

52. Beck IM, Vanden Berghe W, Vermeulen L, Yamamoto KR, Haegeman G and De Bosscher K. Crosstalk in inflammation: the interplay of glucocorticoid receptorbased mechanisms and kinases and phosphatases. Endocr Rev. 2009; 30(7):830-882.

53. Kadmiel M and Cidlowski JA. Glucocorticoid receptor signaling in health and disease. Trends Pharmacol Sci. 2013; 34(9):518-530.

54. Deng Q, Riquelme D, Trinh L, Low MJ, Tomic M, Stojilkovic S and Aguilera G. Rapid Glucocorticoid Feedback Inhibition of ACTH Secretion Involves LigandDependent Membrane Association of Glucocorticoid Receptors. Endocrinology. 2015; 156(9):3215-3227.

55. Boncompagni S, Arthurton L, Akujuru E, Pearson T, Steverding D, Protasi F and Mutungi G. Membrane glucocorticoid receptors are localised in the extracellular matrix and signal through the MAPK pathway in mammalian skeletal muscle fibres. J Physiol. 2015; 593(12):2679-2692.

56. Kfir-Erenfeld S and Yefenof E. Non-genomic events determining the sensitivity of hemopoietic malignancies to glucocorticoid-induced apoptosis. Cancer Immunol Immunother. 2014; 63(1):37-43.

57. Sionov RV, Kfir S, Zafrir E, Cohen O, Zilberman Y and Yefenof E. Glucocorticoid-induced apoptosis revisited: a novel role for glucocorticoid receptor translocation to the mitochondria. Cell Cycle. 2006; 5(10):1017-1026.

58. Sionov RV, Cohen O, Kfir S, Zilberman Y and Yefenof E. Role of mitochondrial glucocorticoid receptor in glucocorticoid-induced apoptosis. J Exp Med. 2006; 203(1):189-201.

59. Sionov RV, Spokoini R, Kfir-Erenfeld S, Cohen O and Yefenof E. Mechanisms regulating the susceptibility of hematopoietic malignancies to glucocorticoid-induced apoptosis. Adv Cancer Res. 2008; 101:127-248.

60. Wang H, Li M, Rinehart JJ and Zhang R. Pretreatment with dexamethasone increases antitumor activity of carboplatin and gemcitabine in mice bearing human cancer xenografts: in vivo activity, pharmacokinetics, and clinical implications for cancer chemotherapy. Clin Cancer Res. 2004; 10(5):1633-1644.

61. Wang H, Wang Y, Rayburn ER, Hill DL, Rinehart JJ and
Zhang R. Dexamethasone as a chemosensitizer for breast cancer chemotherapy: potentiation of the antitumor activity of adriamycin, modulation of cytokine expression, and pharmacokinetics. Int J Oncol. 2007; 30(4):947-953.

62. Schaaf MJ and Cidlowski JA. Molecular mechanisms of glucocorticoid action and resistance. J Steroid Biochem Mol Biol. 2002; 83(1-5):37-48.

63. Melarangi T, Zhuang J, Lin K, Rockliffe N, Bosanquet AG, Oates M, Slupsky JR and Pettitt AR. Glucocorticoid resistance in chronic lymphocytic leukaemia is associated with a failure of upregulated Bim/Bcl-2 complexes to activate Bax and Bak. Cell Death Dis. 2012; 3:e372.

64. Jing D, Bhadri VA, Beck D, Thoms JA, Yakob NA, Wong JW, Knezevic K, Pimanda JE and Lock RB. Opposing regulation of BIM and BCL2 controls glucocorticoidinduced apoptosis of pediatric acute lymphoblastic leukemia cells. Blood. 2015; 125(2):273-283.

65. Huang Y, Zhou J, Huang Y, He J, Wang Y, Yang C, Liu D, Zhang L and He F. SARI, a novel target gene of glucocorticoid receptor, plays an important role in dexamethasone-mediated killing of $\mathrm{b}$ lymphoma cells. Cancer Lett. 2016; 373(1):57-66.

66. Malara N, Foca D, Casadonte F, Sesto MF, Macrina L, Santoro L, Scaramuzzino M, Terracciano R and Savino R. Simultaneous inhibition of the constitutively activated nuclear factor kappaB and of the interleukin-6 pathways is necessary and sufficient to completely overcome apoptosis resistance of human U266 myeloma cells. Cell cycle (Georgetown, Tex). 2008; 7(20):3235-3245.

67. Talaber G, Boldizsar F, Bartis D, Palinkas L, Szabo M, Berta G, Setalo G, Jr., Nemeth P and Berki T. Mitochondrial translocation of the glucocorticoid receptor in doublepositive thymocytes correlates with their sensitivity to glucocorticoid-induced apoptosis. Int Immunol. 2009; 21(11):1269-1276.

68. Buda G, Orciuolo E, Carulli G, Galimberti S, Ghio F, Cervetti G, Pelosini M and Petrini M. Bortezomib with thalidomide plus dexamethasone compared with thalidomide plus doxorubicin and dexamethasone as induction therapy in previously untreated multiple myeloma patients. Acta Haematol. 2013; 129(1):35-39.

69. Jo JC, Kang BW, Sym SJ, Lee SS, Jang G, Kim S, Lee DH, Kim SW, Lee JS and Suh C. Initial cytoreductive treatment with thalidomide plus bolus vincristine/doxorubicin and reduced dexamethasone followed by autologous stem cell transplantation for multiple myeloma. Invest New Drugs. 2011; 29(1):175-181.

70. Romano A, Chiarenza A, Conticello C, Cavalli M, Vetro C, Di Raimondo C, Cunsolo R, Palumbo GA and Di Raimondo F. Salvage therapy with pegylated liposomal doxorubicin, bortezomib, cyclophosphamide, and dexamethasone in relapsed/refractory myeloma patients. Eur J Haematol. 2014; 93(3):207-213.

71. Oki Y, Westin JR, Vega F, Chuang H, Fowler N, Neelapu S, Hagemeister FB, McLaughlin P, Kwak LW, Romaguera 
JE, Fanale M, Younes A, Rodriguez MA, Orlowski RZ, Wang M, Ouzounian ST, et al. Prospective phase II study of rituximab with alternating cycles of hyper-CVAD and highdose methotrexate with cytarabine for young patients with high-risk diffuse large B-cell lymphoma. Br J Haematol. 2013; 163(5):611-620.

72. Mitre-Aguilar IB, Cabrera-Quintero AJ and Zentella-Dehesa A. Genomic and non-genomic effects of glucocorticoids: implications for breast cancer. Int J Clin Exp Pathol. 2015; 8(1):1-10.

73. Munstedt K, Borces D, Bohlmann MK, Zygmunt M and von Georgi R. Glucocorticoid administration in antiemetic therapy: is it safe? Cancer. 2004; 101(7):1696-1702.

74. Hartmann WH and Sherlock P. Gastroduodenal metastases from carcinoma of the breast. An adrenal steroid-induced phenomenon. Cancer. 1961; 14:426-431.

75. Sui M, Chen F, Chen Z and Fan W. Glucocorticoids interfere with therapeutic efficacy of paclitaxel against human breast and ovarian xenograft tumors. Int J Cancer. 2006; 119(3):712-717.

76. Brickley DR, Mikosz CA, Hagan CR and Conzen SD. Ubiquitin modification of serum and glucocorticoidinduced protein kinase-1 (SGK-1). J Biol Chem. 2002; 277(45):43064-43070.

77. Wu W, Chaudhuri S, Brickley DR, Pang D, Karrison T and Conzen SD. Microarray analysis reveals glucocorticoidregulated survival genes that are associated with inhibition of apoptosis in breast epithelial cells. Cancer Res. 2004; 64(5):1757-1764.

78. Wu W, Pew T, Zou M, Pang D and Conzen SD. Glucocorticoid receptor-induced MAPK phosphatase-1 (MPK-1) expression inhibits paclitaxel-associated MAPK activation and contributes to breast cancer cell survival. J Biol Chem. 2005; 280(6):4117-4124.

79. Wu W, Zou M, Brickley DR, Pew T and Conzen SD. Glucocorticoid receptor activation signals through forkhead transcription factor $3 \mathrm{a}$ in breast cancer cells. Mol Endocrinol. 2006; 20(10):2304-2314.

80. Abduljabbar R, Negm OH, Lai CF, Jerjees DA, Al-Kaabi M, Hamed MR, Tighe PJ, Buluwela L, Mukherjee A, Green AR, Ali S, Rakha EA and Ellis IO. Clinical and biological significance of glucocorticoid receptor (GR) expression in breast cancer. Breast Cancer Res Treat. 2015; 150(2):335346.

81. DiGiovanni J, Kruszewski FH and Chenicek KJ. Modulation of chrysarobin skin tumor promotion. Carcinogenesis. 1988; 9(8):1445-1450.

82. Strawhecker JM and Pelling JC. Inhibition of mouse skin tumorigenesis by dexamethasone occurs through a Ha-ras-independent mechanism. Carcinogenesis. 1992; 13(11):2075-2080.

83. Budunova IV, Kowalczyk D, Perez P, Yao YJ, Jorcano JL and Slaga TJ. Glucocorticoid receptor functions as a potent suppressor of mouse skin carcinogenesis. Oncogene. 2003;
22(21):3279-3287.

84. Chebotaev D, Yemelyanov A and Budunova I. The mechanisms of tumor suppressor effect of glucocorticoid receptor in skin. Mol Carcinog. 2007; 46(8):732-740.

85. Verma AK, Garcia CT, Ashendel CL and Boutwell RK. Inhibition of 7-bromomethylbenz[a]anthracenepromoted mouse skin tumor formation by retinoic acid and dexamethasone. Cancer Res. 1983; 43(7):3045-3049.

86. Pence BC and Reiners JJ, Jr. Murine epidermal xanthine oxidase activity: correlation with degree of hyperplasia induced by tumor promoters. Cancer Res. 1987; 47(23):6388-6392.

87. Chebotaev D, Yemelyanov A, Zhu L, Lavker RM and Budunova I. The tumor suppressor effect of the glucocorticoid receptor in skin is mediated via its effect on follicular epithelial stem cells. Oncogene. 2007; 26(21):3060-3068.

88. Spiegelman VS, Budunova IV, Carbajal S and Slaga TJ. Resistance of transformed mouse keratinocytes to growth inhibition by glucocorticoids. Mol Carcinog. 1997; 20(1):99-107.

89. Budunova IV, Carbajal S, Kang H, Viaje A and Slaga TJ. Altered glucocorticoid receptor expression and function during mouse skin carcinogenesis. Mol Carcinog. 1997; 18(3):177-185.

90. Dondi D, Maggi R, Scaccianoce E, Martini L, Motta M and Poletti A. Expression and role of functional glucocorticoid receptors in the human androgen-independent prostate cancer cell line, DU145. J Mol Endocrinol. 2001; 26(3):185-191.

91. Smith RG, Syms AJ, Nag A, Lerner S and Norris JS. Mechanism of the glucocorticoid regulation of growth of the androgen-sensitive prostate-derived R3327H-G8-A1 tumor cell line. J Biol Chem. 1985; 260(23):12454-12463.

92. Yano A, Fujii Y, Iwai A, Kawakami S, Kageyama $\mathrm{Y}$ and Kihara K. Glucocorticoids suppress tumor lymphangiogenesis of prostate cancer cells. Clin Cancer Res. 2006; 12(20 Pt 1):6012-6017.

93. Nishimura K, Nonomura N, Satoh E, Harada Y, Nakayama M, Tokizane T, Fukui T, Ono Y, Inoue H, Shin M, Tsujimoto Y, Takayama H, Aozasa K and Okuyama A. Potential mechanism for the effects of dexamethasone on growth of androgen-independent prostate cancer. J Natl Cancer Inst. 2001; 93(22):1739-1746.

94. Arora VK, Schenkein E, Murali R, Subudhi SK, Wongvipat J, Balbas MD, Shah N, Cai L, Efstathiou E, Logothetis C, Zheng D and Sawyers CL. Glucocorticoid receptor confers resistance to antiandrogens by bypassing androgen receptor blockade. Cell. 2013; 155(6):1309-1322.

95. Isikbay M, Otto K, Kregel S, Kach J, Cai Y, Vander Griend DJ, Conzen SD and Szmulewitz RZ. Glucocorticoid receptor activity contributes to resistance to androgentargeted therapy in prostate cancer. Horm Cancer. 2014; 5(2):72-89. 
96. Chapman KE, Coutinho AE, Zhang Z, Kipari T, Savill JS and Seckl JR. Changing glucocorticoid action: 11betahydroxysteroid dehydrogenase type 1 in acute and chronic inflammation. J Steroid Biochem Mol Biol. 2013; 137:8292.

97. Zhang C, Mattern J, Haferkamp A, Pfitzenmaier J, Hohenfellner M, Rittgen W, Edler L, Debatin KM, Groene E and Herr I. Corticosteroid-induced chemotherapy resistance in urological cancers. Cancer Biol Ther. 2006; 5(1):59-64.

98. Rieger J, Durka S, Streffer J, Dichgans J and Weller M. Gemcitabine cytotoxicity of human malignant glioma cells: modulation by antioxidants, BCL-2 and dexamethasone. Eur J Pharmacol. 1999; 365(2-3):301-308.

99. Gorman AM, Hirt UA, Orrenius S and Ceccatelli S. Dexamethasone pre-treatment interferes with apoptotic death in glioma cells. Neuroscience. 2000; 96(2):417-425.

100. Wolff JE and Jurgens H. Dexamethasone induced partial resistance to methotrexate in C6-glioma cells. Anticancer Res. 1994; 14(4a):1585-1588.

101. Benedetti S, Pirola B, Poliani PL, Cajola L, Pollo B, Bagnati R, Magrassi L, Tunici P and Finocchiaro G. Dexamethasone inhibits the anti-tumor effect of interleukin 4 on rat experimental gliomas. Gene Ther. 2003; 10(2):188192.

102. Feng Z, Marti A, Jehn B, Altermatt HJ, Chicaiza G and Jaggi R. Glucocorticoid and progesterone inhibit involution and programmed cell death in the mouse mammary gland. J Cell Biol. 1995; 131(4):1095-1103.

103. Mikosz CA, Brickley DR, Sharkey MS, Moran TW and Conzen SD. Glucocorticoid receptor-mediated protection from apoptosis is associated with induction of the serine/ threonine survival kinase gene, sgk-1. J Biol Chem. 2001; 276(20):16649-16654.

104. Messmer UK, Pereda-Fernandez C, Manderscheid M and Pfeilschifter J. Dexamethasone inhibits TNF-alpha-induced apoptosis and IAP protein downregulation in MCF-7 cells. Br J Pharmacol. 2001; 133(4):467-476.

105. Herr I, Ucur E, Herzer K, Okouoyo S, Ridder R, Krammer PH, von Knebel Doeberitz M and Debatin KM. Glucocorticoid cotreatment induces apoptosis resistance toward cancer therapy in carcinomas. Cancer Res. 2003; 63(12):3112-3120.

106. Zhang C, Marme A, Wenger T, Gutwein P, Edler L, Rittgen W, Debatin KM, Altevogt P, Mattern J and Herr I. Glucocorticoid-mediated inhibition of chemotherapy in ovarian carcinomas. Int J Oncol. 2006; 28(2):551-558.

107. Chen YX, Wang Y, Fu CC, Diao F, Song LN, Li ZB, Yang $\mathrm{R}$ and $\mathrm{Lu} \mathrm{J}$. Dexamethasone enhances cell resistance to chemotherapy by increasing adhesion to extracellular matrix in human ovarian cancer cells. Endocr Relat Cancer.
2010; 17(1):39-50.

108. Zhang C, Kolb A, Mattern J, Gassler N, Wenger T, Herzer K, Debatin KM, Buchler M, Friess H, Rittgen W, Edler L and Herr I. Dexamethasone desensitizes hepatocellular and colorectal tumours toward cytotoxic therapy. Cancer Lett. 2006; 242(1):104-111.

109. Yang N, Zhang H, Si-Ma H, Fu Y, Zhao W, Li D and Yang G. Dexamethasone decreases hepatocellular carcinoma cell sensitivity to cisplatin-induced apoptosis. Hepatogastroenterology. 2011; 58(110-111):1730-1735.

110. Zhang C, Kolb A, Buchler P, Cato AC, Mattern J, Rittgen W, Edler L, Debatin KM, Buchler MW, Friess H and Herr I. Corticosteroid co-treatment induces resistance to chemotherapy in surgical resections, xenografts and established cell lines of pancreatic cancer. BMC Cancer. 2006; 6:61.

111. Green SB, Byar DP, Walker MD, Pistenmaa DA, Alexander E, Jr., Batzdorf U, Brooks WH, Hunt WE, Mealey J, Jr., Odom GL, Paoletti P, Ransohoff J, 2nd, Robertson JT, Selker RG, Shapiro WR, Smith KR, Jr., et al. Comparisons of carmustine, procarbazine, and highdose methylprednisolone as additions to surgery and radiotherapy for the treatment of malignant glioma. Cancer Treat Rep. 1983; 67(2):121-132.

112. Postmus PE, Smit EF, Haaxma-Reiche H, van Zandwijk N, Ardizzoni A, Quoix E, Kirkpatrick A, Sahmoud T and Giaccone G. Teniposide for brain metastases of smallcell lung cancer: a phase II study. European Organization for Research and Treatment of Cancer Lung Cancer Cooperative Group. J Clin Oncol. 1995; 13(3):660-665.

113. Crokart N, Jordan BF, Baudelet C, Cron GO, Hotton J, Radermacher K, Gregoire V, Beghein N, Martinive $\mathrm{P}$, Bouzin C, Feron $\mathrm{O}$ and Gallez B. Glucocorticoids modulate tumor radiation response through a decrease in tumor oxygen consumption. Clin Cancer Res. 2007; 13(2 Pt 1):630-635.

114. Kamradt MC, Mohideen N, Krueger E, Walter S and Vaughan AT. Inhibition of radiation-induced apoptosis by dexamethasone in cervical carcinoma cell lines depends upon increased HPV E6/E7. Br J Cancer. 2000; 82(10):1709-1716.

115. Llaguno-Munive M, Medina LA, Jurado R, Romero-Pina $\mathrm{M}$ and Garcia-Lopez P. Mifepristone improves chemoradiation response in glioblastoma xenografts. Cancer Cell Int. 2013; 13(1):29.

116. Kamradt MC, Mohideen N and Vaughan AT. RU486 increases radiosensitivity and restores apoptosis through modulation of HPV E6/E7 in dexamethasone-treated cervical carcinoma cells. Gynecol Oncol. 2000; 77(1):177182.

117. Reichardt HM, Kaestner KH, Tuckermann J, Kretz O, Wessely O, Bock R, Gass P, Schmid W, Herrlich P, Angel P 
and Schutz G. DNA binding of the glucocorticoid receptor is not essential for survival. Cell. 1998; 93(4):531-541.

118. Schmid W, Cole TJ, Blendy JA and Schutz G. Molecular genetic analysis of glucocorticoid signalling in development. J Steroid Biochem Mol Biol. 1995; 53(16):33-35.

119. Belvisi MG, Brown TJ, Wicks S and Foster ML. New Glucocorticosteroids with an improved therapeutic ratio? Pulm Pharmacol Ther. 2001; 14(3):221-227.

120. Schacke H, Docke WD and Asadullah K. Mechanisms involved in the side effects of glucocorticoids. Pharmacol Ther. 2002; 96(1):23-43.

121. Schiller BJ, Chodankar R, Watson LC, Stallcup MR and Yamamoto KR. Glucocorticoid receptor binds half sites as a monomer and regulates specific target genes. Genome Biol. 2014; 15(7):418.

122. Lim HW, Uhlenhaut NH, Rauch A, Weiner J, Hubner S, Hubner N, Won KJ, Lazar MA, Tuckermann J and Steger DJ. Genomic redistribution of GR monomers and dimers mediates transcriptional response to exogenous glucocorticoid in vivo. Genome Res. 2015; 25(6):836-844.

123. Sharma S and Lichtenstein A. Dexamethasone-induced apoptotic mechanisms in myeloma cells investigated by analysis of mutant glucocorticoid receptors. Blood. 2008; 112(4):1338-1345.

124. Bardon S, Vignon F, Chalbos D and Rochefort H. RU486, a progestin and glucocorticoid antagonist, inhibits the growth of breast cancer cells via the progesterone receptor. J Clin Endocrinol Metab. 1985; 60(4):692-697.

125. Skor MN, Wonder EL, Kocherginsky M, Goyal A, Hall BA, Cai Y and Conzen SD. Glucocorticoid receptor antagonism as a novel therapy for triple-negative breast cancer. Clin Cancer Res. 2013; 19(22):6163-6172.

126. Dezitter X, Fagart J, Taront S, Fay M, Masselot B, Hetuin $\mathrm{D}$, Formstecher $\mathrm{P}$, Rafestin-Oblin $\mathrm{ME}$ and Idziorek $\mathrm{T}$. A structural explanation of the effects of dissociated glucocorticoids on glucocorticoid receptor transactivation. Mol Pharmacol. 2014; 85(2):226-236.

127. Presman DM, Ogara MF, Stortz M, Alvarez LD, Pooley JR, Schiltz RL, Grontved L, Johnson TA, Mittelstadt PR, Ashwell JD, Ganesan S, Burton G, Levi V, Hager GL and Pecci A. Live cell imaging unveils multiple domain requirements for in vivo dimerization of the glucocorticoid receptor. PLoS Biol. 2014; 12(3):e1001813.

128. Drebert Z, Bracke M and Beck IM. Glucocorticoids and the non-steroidal selective glucocorticoid receptor modulator, compound A, differentially affect colon cancer-derived myofibroblasts. J Steroid Biochem Mol Biol. 2015; 149:92105.

129. Beck IM, Drebert ZJ, Hoya-Arias R, Bahar AA, Devos M, Clarisse D, Desmet S, Bougarne N, Ruttens B, Gossye V, Denecker G, Lievens S, Bracke M, Tavernier J, Declercq W, Gevaert K, et al. Compound A, a selective glucocorticoid receptor modulator, enhances heat shock protein Hsp70 gene promoter activation. PLoS One. 2013; 8(7):e69115.

130. Dewint P, Gossye V, De Bosscher K, Vanden Berghe W, Van Beneden K, Deforce D, Van Calenbergh S, Muller-Ladner U, Vander Cruyssen B, Verbruggen G, Haegeman G and Elewaut D. A plant-derived ligand favoring monomeric glucocorticoid receptor conformation with impaired transactivation potential attenuates collagen-induced arthritis. J Immunol. 2008; 180(4):2608-2615.

131. Alvarez LD, Marti MA, Veleiro AS, Misico RI, Estrin DA, Pecci A and Burton G. Hemisuccinate of 21-hydroxy6,19-epoxyprogesterone: a tissue-specific modulator of the glucocorticoid receptor. ChemMedChem. 2008; 3(12):1869-1877.

132. Alvarez LD, Marti MA, Veleiro AS, Presman DM, Estrin DA, Pecci A and Burton G. Exploring the molecular basis of action of the passive antiglucocorticoid 21-hydroxy-6,19epoxyprogesterone. J.Med. Chem. 2008; 51(5):1352-1360.

133. De Bosscher K, Beck IM, Dejager L, Bougarne N, Gaigneaux A, Chateauvieux S, Ratman D, Bracke M, Tavernier J, Vanden Berghe W, Libert C, Diederich M and Haegeman G. Selective modulation of the glucocorticoid receptor can distinguish between transrepression of NFkappaB and AP-1. Cell Mol Life Sci. 2014; 71(1):143-163.

134. Chivers JE, Gong W, King EM, Seybold J, Mak JC, Donnelly LE, Holden NS and Newton R. Analysis of the dissociated steroid RU24858 does not exclude a role for inducible genes in the anti-inflammatory actions of glucocorticoids. Mol Pharmacol. 2006; 70(6):2084-2095.

135. Vanden Berghe W, Francesconi E, De Bosscher K, RescheRigon M and Haegeman G. Dissociated glucocorticoids with anti-inflammatory potential repress interleukin-6 gene expression by a nuclear factor-kappaB-dependent mechanism. Mol Pharmacol. 1999; 56(4):797-806.

136. Zhang Z, Zhang ZY and Schluesener HJ. Compound A, a plant origin ligand of glucocorticoid receptors, increases regulatory $\mathrm{T}$ cells and M2 macrophages to attenuate experimental autoimmune neuritis with reduced side effects. J Immunol. 2009; 183(5):3081-3091.

137. Klopot A, Baida G, Bhalla P, Haegeman G and Budunova I. Selective Activator of the Glucocorticoid Receptor Compound A Dissociates Therapeutic and Atrophogenic Effects of Glucocorticoid Receptor Signaling in Skin. J Cancer Prev. 2015; 20(4):250-259.

138. van Loo G, Sze M, Bougarne N, Praet J, Mc Guire C, Ullrich A, Haegeman G, Prinz M, Beyaert R and De Bosscher K. Antiinflammatory properties of a plant-derived nonsteroidal, dissociated glucocorticoid receptor modulator in experimental autoimmune encephalomyelitis. Mol Endocrinol. 2010; 24(2):310-322.

139. Gossye V, Elewaut D, Van Beneden K, Dewint P, Haegeman $\mathrm{G}$ and De Bosscher K. A plant-derived glucocorticoid receptor modulator attenuates inflammation without provoking ligand-induced resistance. Ann Rheum Dis. 2010; 69(1):291-296.

140. Viaje A, Slaga TJ, Wigler M and Weinstein IB. Effects of 
antiinflammatory agents on mouse skin tumor promotion, epidermal DNA synthesis, phorbol ester-induced cellular proliferation, and production of plasminogen activator. Cancer Res. 1977; 37(5):1530-1536.

141. Lowe NJ, Connor MJ, Breeding J and Chalet M. Inhibition of ultraviolet-B epidermal ornithine decarboxylase induction and skin carcinogenesis in hairless mice by topical indomethacin and triamcinolone acetonide. Cancer Res. 1982; 42(10):3941-3943.

142. Ueno H, Maruyama A, Miyake M, Nakao E, Nakao K, Umezu K and Nitta I. Synthesis and evaluation of antiinflammatory activities of a series of corticosteroid 17 alpha-esters containing a functional group. J Med Chem. 1991; 34(8):2468-2473.

143. Hayashi R, Wada H, Ito K and Adcock IM. Effects of glucocorticoids on gene transcription. Eur J Pharmacol. 2004; 500(1-3):51-62.

144. Hamalainen M, Lilja R, Kankaanranta H and Moilanen E. Inhibition of iNOS expression and NO production by anti-inflammatory steroids. Reversal by histone deacetylase inhibitors. Pulm Pharmacol Ther. 2008; 21(2):331-339.

145. Pecci A, Alvarez LD, Presman DM and Burton G. 21-hydroxy-6,19-epoxyprogesterone: a Promising Therapeutic Agent and a Molecular Tool for Deciphering Glucocorticoid Action. Mini Rev Med Chem. 2016.

146. Haridas V, Li X, Mizumachi T, Higuchi M, Lemeshko VV, Colombini $\mathrm{M}$ and Gutterman JU. Avicins, a novel plantderived metabolite lowers energy metabolism in tumor cells by targeting the outer mitochondrial membrane. Mitochondrion. 2007; 7(3):234-240.

147. Xu ZX, Liang J, Haridas V, Gaikwad A, Connolly FP, Mills GB and Gutterman JU. A plant triterpenoid, avicin D, induces autophagy by activation of AMP-activated protein kinase. Cell Death Differ. 2007; 14(11):1948-1957.

148. McConkey DJ and Zhu K. Mechanisms of proteasome inhibitor action and resistance in cancer. Drug Resist Updat. 2008; 11(4-5):164-179.

149. Horton TM, Gannavarapu A, Blaney SM, D'Argenio DZ, Plon SE and Berg SL. Bortezomib interactions with chemotherapy agents in acute leukemia in vitro. Cancer Chemother Pharmacol. 2006; 58(1):13-23.

150. Kraus M, Malenke E, Gogel J, Muller H, Ruckrich T, Overkleeft H, Ovaa H, Koscielniak E, Hartmann JT and Driessen C. Ritonavir induces endoplasmic reticulum stress and sensitizes sarcoma cells toward bortezomib-induced apoptosis. Mol Cancer Ther. 2008; 7(7):1940-1948.

151. Riggs BL and Hartmann LC. Selective estrogen-receptor modulators -- mechanisms of action and application to clinical practice. TN Engl J Med. 2003; 348(7):618-629.

152. von Geldern TW, Tu N, Kym PR, Link JT, Jae HS, Lai C, Apelqvist T, Rhonnstad P, Hagberg L, Koehler K, Grynfarb M, Goos-Nilsson A, Sandberg J, Osterlund M, Barkhem T, Hoglund $\mathrm{M}$, et al. Liver-selective glucocorticoid antagonists: a novel treatment for type 2 diabetes. J Med
Chem. 2004; 47(17):4213-4230.

153. Kroon J, Buijs JT, van der Horst G, Cheung H, van der Mark M, van Bloois L, Rizzo LY, Lammers T, Pelger RC, Storm G, van der Pluijm G and Metselaar JM. Liposomal delivery of dexamethasone attenuates prostate cancer bone metastatic tumor growth in vivo. Prostate. 2015; 75(8):815824.

154. Rathore B, Chandra Sekhar Jaggarapu MM, Ganguly A, Reddy Rachamalla HK and Banerjee R. Cationic lipidconjugated hydrocortisone as selective antitumor agent. Eur J Med Chem. 2016; 108:309-321.

155. Kach J, Conzen SD and Szmulewitz RZ. Targeting the glucocorticoid receptor in breast and prostate cancers. Sci Transl Med. 2015; 7(305):305ps319.

156. Robertson S, Allie-Reid F, Vanden Berghe W, Visser K, Binder A, Africander D, Vismer M, De Bosscher K, Hapgood J, Haegeman G and Louw A. Abrogation of glucocorticoid receptor dimerization correlates with dissociated glucocorticoid behavior of compound a. J Biol Chem. 2010; 285(11):8061-8075.

157. Ronacher K, Hadley K, Avenant C, Stubsrud E, Simons SS, Jr., Louw A and Hapgood JP. Ligand-selective transactivation and transrepression via the glucocorticoid receptor: role of cofactor interaction. Mol Cell Endocrinol. 2009; 299(2):219-231. 